The Chittagong Univ. J. B. Sci., Vol. 3(1 \&2):pp. 53-64, 2008.

\title{
BIOLOGICAL EVALUATION OF SOME OCTANOYL DERIVATIVES OF METHYL 4,6-O-CYCLOHEXYLIDENE- $\alpha$-D- GLUCOPYRANOSIDE.
}

\author{
ABUL K. M. S. KABIR*, SARKAR M. A. KAWSAR, MOHAMMAD M. R. \\ BHUIYAN, MD. SAFIQUR RAHMAN** AND BILKISS BANU \\ *Department of Chemistry, **Department of Microbiology, University of Chittagong, Chittagong- \\ 4331, Bangladesh.
}

\begin{abstract}
Some acylated derivatives of methyl 4,6- $O$-cyclohexylidene- $\alpha$-Dglucopyranoside, including the precursor, were employed as test compounds for in vitro antimicrobial functionality test against ten human pathogenic bacteria and six phytopathogenic fungi. For comparative studies, biological activity of standard antibiotics, Ampicillin and Nystatin were also carried out against these microorganisms. The study revealed that the tested samples exhibited moderate to good antibacterial and antifungal activities. It was also observed that the test substances were more effective against fungal phytopathogens than those of the bacterial strains. Encouragingly, a good number of test compounds exhibited better antimicrobial activity than the standard antibiotics employed. Minimum Inhibition Concentration (MIC) test of methyl 4,6- $O$-cyclohexylidene-3-Odecanoyl-2- $O$-octanoyl- $\alpha$-D-glucopyranoside was conducted against INABA ET (Vibrio) and MIC was found to be $12.5 \mu \mathrm{g} /$ disc.
\end{abstract}

Key words: Antimicrobial activities, Gram-positive bacteria, Gram-negative bacteria, Fungal Inhibition.

\section{INTRODUCTION}

During the last few decades, considerable works have been done in the field of biological evaluation of various chemical compounds (Singh et al. 1990). Carbohydrates, especially- acylated glycoses and glycosides, are very important due to their effective biological activity. It is known that if an active nucleus is linked to another nucleus, the resultant molecule may possess greater potential for biological activity (Gupta et al. 1997). From literature survey, it was revealed(Ghorab et al. 2004) that a large number of biological compounds possess aromatic, heteroaromatic and acyl substituents. Nitrogen, sulphur and halogen

\footnotetext{
* Corresponding author.
} 
containing substituents are also known to enhance the biological activity of the parent compound (Ghorab et al. 1988).

Over the last few years, researchers in our laboratory carried out selective acylation of monosaccharide derivatives (Kabir et al. 2002-2004) and also biological evaluation of the synthesised compounds (Kabir et al. 2004, 2005). It was observed that the combination of two or more acyl substituents in a single molecular framework enhances the biological activity many fold than their parent nuclei. For example, some acylated derivatives of D-glucopyranose were found more active than those of the standard antibiotics (Kabir et al. 2001).

Encouraged by these results and literature reports, we synthesised some acyl derivatives of methyl 4,6- $O$-cyclohexylidene- $\alpha$-D-glucopyranoside containing a cyclohexane moiety and various acyl groups (e.g. octanoyl, decanoyl, lauroyl, myristoyl, palmitoyl, acetyl, benzoyl, 2-chlorobenzoyl, 4-chlorobenzoyl, mesyl, brosyl and pivaloyl) in a single molecular framework. Antimicrobial activities of these compounds were carried out using a variety of bacterial and fungal strains and the results are reported here.

\section{MATERIALS AND METHODS}

\section{Test bacteria}

Compounds 1-13 were tested for their antibacterial activities against four Gram-positive and six Gram-negative bacterial strains, viz. Bacillus subtilis BTCC 17 , B. cereus BTCC 19, B. megaterium BTCC 18, Staphylococcus aureus ATCC 653, Escherichia coli ATCC 25922, Salmonella typhi AE 14612, $S$. paratyphi CRL(ICDDR,B), Shigella sonnei CRL (ICDDR,B), S. dysenteriae AE 14396 and INABA ET (Vibrio).

Test fungi

The test chemicals 1-13 were screened for their antifungal activities against six phytopathogenic fungi, viz., Fusarim equiseti (corda) Sacc., Macrophomina Phaseolina (Tassi) Goid, Colletotrichum corchori (Ikata Yoshida), Botrydiplodia theobromae (pat), Curvularia lunata (Wakker Becdijin) and Alternaria alternata (Fr.) Kedissler. Methyl 4,6-O-cyclohexylidene- $\alpha$-Dglucopyranoside (1) and its acylated derivatives (2-13) were used as test chemicals for the determination of antimicrobial (bacteria and fungi) activities. The tested chemicals (Fig.-1, 1-13) were synthesised, isolated and purified at the Organic Research Laboratory of the Department of Chemistry, University of Chittagong. In all cases, a $2 \%$ solution (in $\mathrm{CHCl}_{3}$ ) of the chemicals was used. The test tube cultures of bacterial and fungal pathogens were collected from the 


\section{BIOLOGICAL EVALUATION OF SOME OCTANOYL DERIVATIVES}

Microbiology Research Laboratory, Department of Microbiology, University of Chittagong.

\section{Antibacterial Studies}

In vitro antibacterial activities of the test compounds were studied by disc diffusion method (Bauer et al. 1966) and Nutrient Agar (NA) medium was used for culture of bacteria. Paper discs of $4 \mathrm{~mm}$ in diameter were sterilised in an autoclave and dried at $100^{\circ} \mathrm{C}$ in an oven. Then the discs were soaked with test samples at the rate of $50 \mu \mathrm{g}$ (dry weight) per disc for antibacterial analysis. For pour plate method, one drop of bacterial suspension was taken in a sterile petridish and approximately $20 \mathrm{ml}$ of sterilised melted NA $\left(\sim 45^{\circ} \mathrm{C}\right)$ was poured to the plate, then mixed thoroughly with the direction of clockwise and anticlockwise. After solidification of the seeded NA medium, paper disc after soaking with test samples were placed at the centre of the inoculated pour plate. A control plate was also maintained in each case with chloroform. Firstly, the plates were kept for $4 \mathrm{hrs}$ at low temperature $\left(4^{0} \mathrm{C}\right)$ and the test compounds diffused from disc to the surrounding medium by this time. The plates were then incubated at $(35 \pm 2)^{0} \mathrm{C}$ for growth of test organisms and were observed at $24 \mathrm{hrs}$. intervals for two days. The activity was expressed in terms of inhibition zone diameter in $\mathrm{mm}$. Each experiment was repeated thrice. The standard antibiotic Ampicillin (for bacteria) from FISONS (Bangladesh) Ltd. was used as a positive control and compared with tested chemicals under identical conditions.

\section{Antifungal Studies}

In vitro antifungal activities were determined by poisoned food technique (Grover and Moore 1962) in some modified conditions (Miah et al. 1990) and Potato Dextrose Agar (PDA) medium was used for culture of fungi. Required amount of medium was taken in conical flasks separately and was sterilised in an autoclave at $120^{\circ} \mathrm{C}$ and $15 \mathrm{psi}$. After autoclaving, weighed amount of test chemical was added to this medium in conical flask at the point of pouring to obtain the desired concentration. The flask was shaken thoroughly to mix the chemical with the medium before pouring. The medium with definite amount of chemical $(100 \mu \mathrm{g})$ was then poured into separate sterilised petridishes. Proper control was maintained separately with sterilised PDA medium without chemical and three replicates were prepared for each treatment.

After solidification of medium, the plates were of mycelial blocks ( $5 \mathrm{~mm}$ aprox.) of individual test fungus, cut out from the outer margin of the growing cultures on PDA plates. The blocks were then placed at the centre of each petridish in an inverted position. All the plates were inoculated at $(25 \pm 2)^{0} \mathrm{C}$ for $3-5$ days. 
KABIR ET AL.

The linear mycelial growth of fungal colony was measured in two directions at right angle to each other after 3-5 days of incubation and average of three replicates was taken as the diameter of the colony in $\mathrm{mm}$. The percentage inhibition of mycelial growth of test fungi was calculated as follows :

$\mathrm{I}=\left\{\frac{\mathrm{C}-\mathrm{T}}{\mathrm{C}}\right\} \times 100$

Where, $\mathrm{I}=$ Percentage of inhibition, $\mathrm{C}=$ Diameter of the fungal colony in control $\left(\mathrm{CHCl}_{3}\right)$,

$\mathrm{T}=$ Diameter of the fungal colony in treatment.

The antifungal results were compared with that of the standard antibiotic, Nystatin.

\section{RESULTS AND DISCUSSION}

In the present investigation, the test compounds (2-13) were prepared from a common precursor, namely, methyl 4,6- $O$-cyclohexylidene- $\alpha$-Dglucopyranoside (1). These test samples (1-13) contain a wide variety of substituents. These substituent groups were deliberately introduced to the Dglucose molecule in order to study their effectiveness towards various microorganisms. Thus, the test substances (1-13) were screened for their antimicrobial activity against ten human pathogenic bacteria and six phytopathogenic fungi. For comparative study, the antimicrobial activity of two standard antibiotics, Ampicillin and Nystatin, were also evaluated against these micro-organisms. The results of antibacterial activity studies of the test chemicals are presented in Table- 1 and Table-2.

TABLE-1: ZONE OF INHIBITION OBSERVED AGAINST GRAM-POSITIVE TEST ORGANISM (BACTERIA) BY THE TEST COMPOUNDS.

\begin{tabular}{ccccc}
\hline Compound & \multicolumn{4}{c}{ Diameter of inhibition zone in mm. } \\
\cline { 2 - 5 } No. & Bacillus subtilis & B. cereus & B. megaterium & Staphylococcus aureus \\
\hline 1 & 00 & 01 & 02 & 04 \\
2 & 08 & 09 & 10 & $* 22$ \\
3 & --- & --- & --- & --- \\
4 & --- & --- & --- & 13 \\
5 & --- & --- & --- & --- \\
6 & --- & --- & --- & 10
\end{tabular}


BIOLOGICAL EVALUATION OF SOME OCTANOYL DERIVATIVES

$\begin{array}{ccccc}7 & 08 & 08 & * 18 & 15 \\ 8 & 10 & 10 & * 16 & * 17 \\ 9 & 07 & --- & --- & 06 \\ 10 & * 12 & * 14 & 15 & 15 \\ 11 & 10 & 12 & * 16 & * 16 \\ 12 & 08 & 12 & 10 & 10 \\ 13 & --- & --- & --- & 12 \\ * * \text { Ampicillin } & * 19 & * 18 & * 16 & * 22 \\ 200 \mu \mathrm{gg} & & & & \\ \text { dw./disc } & & & & \end{array}$

N.B.: “*” = Means marked inhibition, “**" = Means standard inhibition of antibiotic "---" = Means no inhibition, "dw" = Means dry weight

TABLE-2 : ZONE OF INHIBITION OBSERVED AGAINST GRAM-NEGATIVE TEST ORGANISM (BACTERIA) BY THE TEST COMPOUNDS.

\begin{tabular}{|c|c|c|c|c|c|c|}
\hline \multirow{2}{*}{$\begin{array}{c}\text { Compound } \\
\text { No. }\end{array}$} & \multicolumn{6}{|c|}{ Diameter of Zone of inhibition in $\mathrm{mm} 200 \mu \mathrm{g} \mathrm{dw} . /$ disc } \\
\hline & E. coli & S. typhi & S. paratyphi & S.dysenteriae & S. Sonnei & $\begin{array}{c}\text { INABA ET } \\
(\text { Vibrio })\end{array}$ \\
\hline 1 & 01 & 02 & 01 & 00 & 05 & 03 \\
\hline 2 & 16 & 10 & 10 & 12 & 12 & 10 \\
\hline 3 & -- & --- & --- & --- & --- & --- \\
\hline 4 & --- & --- & --- & --- & --- & --- \\
\hline 5 & --- & 10 & --- & --- & --- & --- \\
\hline 6 & 10 & 12 & 10 & --- & 06 & 10 \\
\hline 7 & $* 20$ & 07 & 12 & 07 & 08 & 10 \\
\hline 8 & 17 & 08 & 10 & 06 & --- & 15 \\
\hline 9 & --- & --- & --- & 07 & --- & --- \\
\hline 10 & $* 20$ & 09 & 12 & 09 & 10 & $* 20$ \\
\hline 11 & 10 & 10 & 12 & 10 & 08 & 15 \\
\hline-9 & & & 57 & & & \\
\hline
\end{tabular}


KABIR ET AL.

$\begin{array}{ccccccc}12 & 12 & 08 & 08 & 08 & 06 & 08 \\ 13 & 08 & 06 & --- & --- & 09 & --- \\ * * \text { Ampicill } & & & & & & * 15 \\ \text { in }(200 \mu \mathrm{g} & * 10 & * 20 & * 18 & * 22 & * 20 & \\ \mathrm{dw} . / \text { disc }) & & & & & & \end{array}$

N.B. : “*” $=$ Means marked inhibition, " $* * *=$ Means standard inhibition of antibiotic

$$
\text { “---" = Means no inhibition, “dw”= Means dry weight }
$$

\section{Bacillus subtilis BTCC 17.}

The inhibition growth data indicated that the test sample 10 was more effective than that of others. Whereas, the rest of the compounds had no effect on this micro-organism. All of these test samples were, however, less active against this bacterial strain than the standard antibiotic, Ampicillin $(19 \mathrm{~mm})$.

\section{Bacillus cereus BTCC 19}

It was found that the compound 10 was more effective than that of others such as, 2, 7, 8, 11 and 12, which were somewhat less effective. The rest of the compounds such as 3, 4, 5, 6 and 13 did not show any inhibition. All of these test compounds were, however, less active against this bacterial strain than Ampicillin (18 mm).

\section{Bacillus megaterium BTCC 18}

Test compound 7 was found to be more effective against this bacterium $(18 \mathrm{~mm})$ than Ampicillin $(16 \mathrm{~mm})$. The compounds 2, 8, 10,11 and 12 were less effective and the inhibition zone for the rest were found to be zero.

\section{Staphylococcus aureus ATCC 6538}

Test compound 2 was found to be highly effective against this bacterium (22 mm). Compounds 9, 6 and 12 showed poor inhibition; whereas, compounds 3 and 5 did not show any inhibition.

\section{Escherichia coli ATCC 25922}

Encouragingly, in case of this bacterium, compounds 7 and 10 showed higher inhibition $(20 \mathrm{~mm})$ than Ampicillin (10 mm), whereas, compounds 2, 6, 8, 11, 12 and 13 were moderately effective. Rest of the test samples did not show any inhibition at all. 


\section{BIOLOGICAL EVALUATION OF SOME OCTANOYL DERIVATIVES}

\section{Salmmonella typhi AE 14612.}

The screening data shown in Table-2 suggest that the test compounds 5 and 6 were more effective than other compounds. Compounds 2, 7, 8, 10, 11, 12 and 13 were less active against this bacterium, whereas compounds 3, 4 and 9 were found to be inactive.

\section{Salmonella paratyphi CRL (ICDDR, B)}

The inhibition growth data indicated that the chemicals 7, 10 and 11 showed mild inhibition and 2, 6, 8 and 12 were less active against this bacterium. The rest of the compounds had no effect on this micro-organism.

\section{Shigella dysenteriae AE 14396}

Test compound 2 showed maximum inhibition $(12 \mathrm{~mm})$ as compared to that of other compounds like 7, 8, 9, 10, 11, 12, and the rest did not show antibacterial functionality. All of these test samples were, however, less active than Ampicillin (22 mm) against this bacterial strain.

\section{Shigella sonnei CRL $(I C D D R, B)$}

Compounds 2, 6, 7, 10,11, 12, 13 were less effective and compounds 3, 4, 5, 8, 9 were found to be inactive against this bacterial strain. In this case also, none of the test compounds were found to be more active than Ampicillin (20 $\mathrm{mm})$.

\section{INABA ET (Vibrio)}

The screening data listed in Table-2 suggest that the octanoyl derivative 10 showed excellent inhibition against this bacterium $(20 \mathrm{~mm})$. Test compounds $2,6,7,8,11,12$ were less effective, whereas the rest of the compounds were unable to show any inhibition against this bacterium. As the test compound 10 showed excellent inhibition, we have performed the MIC test and the results are presented in Table-3.

TABLE-3 : MINIMUM INHIBITION CONCENTRATION (MIC) TEST.

\begin{tabular}{ccccc}
\hline Compound No & $\begin{array}{c}\text { Name of the } \\
\text { Bacteria }\end{array}$ & $\begin{array}{c}\text { Sample Concentration } \\
(\mu \mathrm{g} / \text { disc })\end{array}$ & $\begin{array}{c}\text { Zone of Inhibition } \\
\text { in } \mathrm{nm}\end{array}$ & $\begin{array}{c}\text { MIC } \\
(\mu \mathrm{g} / \mathrm{disc})\end{array}$ \\
\hline \multirow{3}{*}{10} & & 200 & 20 & \\
& & 100 & 15 & \\
& INABA ET & 50 & 12 & 12.5 \\
& $($ Vibrio $)$ & 25 & 10 & \\
& 12.5 & 08 & \\
& 6.25 & -- & \\
\hline
\end{tabular}


From this study, we found that selectively acylated derivatives 2, 7, 8, 10, 11 and 12 showed moderate to marked inhibition against Gram-positive bacteria while compounds 2, 6, 7, 8, 10,11 and 12 are very active against Gram-negative bacteria. We also observed that some compounds such as, 2, 7, 8, 10, 11 and 12 are active against both the Gram-positive and Gram-negative organisms. So these compounds may be targeted for future studies for their usage as broad spectrum antibiotics.

MIC methods are widely used in the comparative testing of new agents. The minimum inhibition concentration (MIC) is the minimum concentration of the antibacterial agent in a given culture medium below which bacterial growth is not inhibited. In clinical laboratories they are used to establish the susceptibility of organisms that give equivocal results in disc tests, for tests on organisms where disc tests were unreliable and when a more accurate result was required for clinical management. The MIC of the test compound 10 was found to be $12.5 \mu \mathrm{g}$ /disc. This MIC value is indicative of the usefulness of this chemical as potential antimicrobial drug but some other experiments must be carried out before this can be used as an effective drug. As compound 10 have shown remarkable inhibitory activity against the potential pathogenic bacteria, i.e. INABA ET (Vibrio), the efficacy of this compound cannot be ignored. The compound should be subjected to further experiments to evaluate its efficacy and this will be the subject of our future research works.

Paper discs were treated with $200 \mu \mathrm{g} /$ disc, $100 \mu \mathrm{g} /$ disc. $50 \mu \mathrm{g} / \mathrm{disc}, 25$ $\mu \mathrm{g} / \mathrm{disc}, 12.5 \mu \mathrm{g} / \mathrm{disc}$ and $6.25 \mu \mathrm{g} / \mathrm{disc}$ for MIC (Minimum inhibition concentration test (Bauer et al. 1966).

Antifungal Activity studies.

The results of the percentage inhibition of mycelial growth due to treatment of compounds are presented in Table-4.

\section{Fusarim equiseti}

The antifungal screening data as presented in Table-4 suggest that test compounds $2(33.90 \%)$ and $7(38.46 \%)$, display marked toxicities towards Fusarim equiseti. The rest of the compounds such as 3, 6, 8, 9, 10, 11, 12 and 13, were less toxic to this fungus as compared to that of the standard antibiotic Nystatin.

\section{Macrophomina phaseolina}

It was found that compounds $6(72.22 \%)$ and $11(72.22 \%)$ showed excellent inhibition against this phytopathogen, showing almost similar activity as Nystatin (71.78\%). The rest of the compounds were either less effective than Nystatin or did not show any inhibition or stimulation. 


\section{BIOLOGICAL EVALUATION OF SOME OCTANOYL DERIVATIVES}

\section{Colletotricum corchor}

From the screening data, we found that most of the acylated derivatives showed moderate to poor inhibition against this plant pathogenic fungus.

\section{Botrydiplodia theobromae}

Compounds 7 (33.33\%), 8 (65.33\%) and 10 (44.00\%) showed moderate to good inhibition against this plant pathogenic fungus and compounds $2(8.00 \%), 3$ $(28.00 \%), 4(10.00 \%), 5(8.00 \%), 6(20.00 \%), 9(20.00 \%)$ and $13(6.67 \%)$, showed moderate to poor inhibition. Whereas, the remaining test samples were found inactive against this phytopathogen.

\section{Curvularia lunata}

The inhibition of mycelial growth of the compounds $2(35.00 \%)$ and $6(34.79 \%)$ showed very effective inhibition, though it was not as effective as Nystatin (75.00\%). We observed that compounds $12(0.00 \%)$ and $13(0.00 \%)$ did not show any inhibition or stimulation. Most of the acylated derivatives, however, showed moderate to poor inhibition against this plant pathogenic fungus.

\section{Alternaria alternata}

It was found that the compound $8(44.73 \%)$ showed very effective inhibition, though it was not as effective as Nystatin (51.55\%). Compounds 2 (15.38\%), 3 (15.38\%), $10(19.23 \%), 12(15.38 \%)$ showed moderate to poor inhibition against this plant pathogenic fungus and the remaining compounds were found to be inactive.

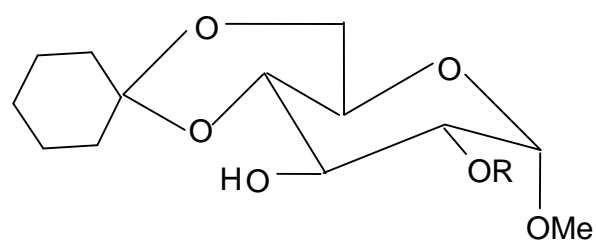

1. $\mathrm{R}=\mathrm{H}$

2. $\mathrm{R}=$ Octanoyl
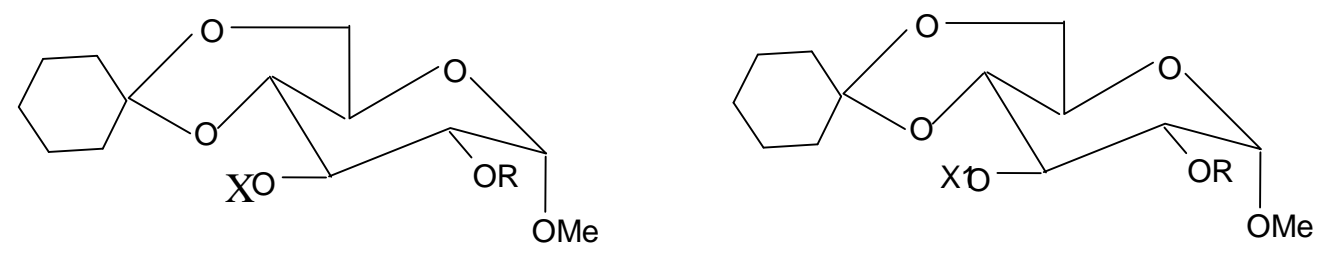

3. $\mathrm{R}=$ Octanoyl; $\mathrm{X}=\mathrm{Ac}$
9. $\mathrm{R}=$ Octanoyl; $\mathrm{X}=\mathrm{Pv}$
4. $\mathrm{R}=$ Octanoyl; $\mathrm{X}=\mathrm{Bz}$
10. $\mathrm{R}=$ Octanoyl; $\mathrm{X}=$ Decanoyl
5. $\mathrm{R}=$ Octanoyl; $\mathrm{X}=2-\mathrm{Cl} . \mathrm{Bz}$
11. $\mathrm{R}=$ Octanoyl; $\mathrm{X}=$ Lauroyl
6. $\mathrm{R}=$ Octanoyl; $\mathrm{X}=4-\mathrm{Cl} . \mathrm{Bz}$
12. $\mathrm{R}=$ Octanoyl; $\mathrm{X}=$ Myristoyl
7. $\mathrm{R}=$ Octanoyl; $\mathrm{X}=\mathrm{Ms}$
13. $\mathrm{R}=$ Octanoyl; $\mathrm{X}=$ Palmitoyl
8. $\mathrm{R}=$ Octanoyl; $\mathrm{X}=\mathrm{Bs}$

\section{FIG.-1 : THE STRUCTURE OF COMPOUNDS 1-13}

The results obtained from the present investigation of antifungal studies mentioned in Table-4 clearly demonstrate that compound 11 showed excellent inhibition in which the percent inhibition (72.22\%) is more than Nystatin (71.78\%) against Macrophomina phaseolina. However, the test compounds (113) were found to be less active or toxic to Curvularia lunata and Alternaria alternata as compared to Nystatin.

TABLE-4 : ANTIFUNGAL ACTIVITIES OF THE COMPOUNDS \& NYSTATIN

\begin{tabular}{ccccccc}
\hline Compound & \multicolumn{5}{c}{ \% Inhibition of fungal mycelial growth, $100 \mu \mathrm{g}(\mathrm{dw})$ sample ml PDA } \\
\cline { 2 - 7 } No. & $\begin{array}{c}\text { Fusarim } \\
\text { equiseti }\end{array}$ & $\begin{array}{c}\text { M. } \\
\text { phaseolina }\end{array}$ & C. corchori & $\begin{array}{c}\text { Botrydiplodia } \\
\text { theobromae }\end{array}$ & $\begin{array}{c}\text { Curvularia } \\
\text { Iunata }\end{array}$ & $\begin{array}{c}\text { Alternaria } \\
\text { alternata. }\end{array}$ \\
\hline 1 & 8.15 & 5.01 & 7.11 & 3.26 & 1.5 & 6.35 \\
2 & $* 33.90$ & --- & 33.33 & 8.00 & $* 35.00$ & 15.38 \\
3 & 10.80 & 11.11 & 12.69 & 28.00 & 20.68 & 15.38 \\
4 & --- & 16.70 & 1.58 & 10.00 & 13.80 & 3.84 \\
5 & --- & --- & --- & 8.00 & 6.89 & 3.84 \\
6 & 15.38 & $* 72.22$ & 34.92 & 20.00 & $* 34.79$ & 7.69 \\
7 & $* 38.46$ & --- & 33.33 & $* 33.33$ & 2.27 & --- \\
8 & 23.07 & 5.55 & 12.69 & $* 65.33$ & 9.09 & $* 44.73$ \\
9 & 4.61 & --- & 11.11 & 20.00 & 3.44 & 3.84 \\
10 & 12.30 & 5.55 & 12.69 & $* 44.00$ & 13.79 & 19.23 \\
11 & 15.38 & $* 72.22$ & 12.69 & --- & 13.63 & --- \\
12 & 12.30 & 11.11 & 9.52 & --- & --- & 15.38
\end{tabular}


BIOLOGICAL EVALUATION OF SOME OCTANOYL DERIVATIVES

$\begin{array}{ccccccc}13 & 13.80 & --- & 7.93 & 6.67 & --- & 10.50 \\ * * \text { Nystatin } & * 44.70 & * 71.78 & * 40.51 & * 70.05 & * 75.00 & * 51.55 \\ (100 \mu \mathrm{g} & & & & & & \end{array}$

$\mathrm{dw} . / \mathrm{disc})$

N.B. : “*” = Means marked inhibition, " $* * * "=$ Means standard antibiotic, “---" = Means no inhibition, "dw" = Means dry weight.

Our synthesised and reported compounds (1-13) have not been tested before against the selected bacterial and fungal pathogens. This is the first report regarding the effectiveness of the selected compounds against the selected pathogens. The results of the present investigation showed that some of the newly synthesised acylaled derivatives of methyl 4,6- $O$-cyclohexylidene- $\alpha-\mathrm{D}$ glucopyranoside may be tested against a wide range of phytopathogenic fungi and bacteria, before sending them to pesticide producing companies for further tests. It is also expected that this piece of work employing carbohydrate derivatives as test compounds will help further work to the development of pesticides and medicine for plant and human disease control. So it is hoped that the acylated derivatives of methyl 4,6- $O$-cyclohexylidene- $\alpha$-D-glucopyranoside (2-13) might show potential antiviral, antituberculatic and anti-inflammatory activities.

\section{ACKNOWLEDGEMENT}

The authors are thankful to the Research Cell, University of Chittagong, for financial assistance to carry out the research project.

\section{REFERENCES}

BAUER, A.W., KIRBY, W.M.M. AND TURK, M. 1966. Antibiotic susceptibility testing by a standard single disk method. Am. J. Clinic. Pathol. 45 : 493-496.

GHORAB, M.M., ISMAIL, Z.H., GAWARD, S.M.A. AND AZIEM, A.A. 2004. Antimicrobial activity of amino acid, imidazole and sulfonamide derivatives of pyrazolo[3,4-d]pyrimidine. Heteroatom Chem. 15 (1) : 57-62.

GROVER, R.K. AND MOORE, J.D. 1962. Toximetric studies of fungisides against brown rot organisms, Sclerotinia flucticola and S. laxa. Phytopathology. 52 : 876-880. 
KABIR ET AL.

GUPTA, R., PAUL, S., GUPTA, A.K., KACHROO, P.L. AND BANI, S. 1997. Synthesis and biological activities of some substituted phenyl-3-(3alkyl/aryl-5,6-dihydro-s-triazolo $\quad[3,4-b][1,3,4]$ thiazol-6-yl) indoles. Indian J. Chem. 36 : 707-710.

KABIR, A.K.M.S., MATIN, M.M. AND SANAULLAH, A.F.M. 2002.

Regioselective synthesis and characterisation of some lyxose derivatives. Celon J. Sci. (Phy. Sci) (Sri Lanka). 9 (2) : 9-14.

KABIR, A.K.M.S., DUTTA, P. AND ANWAR, M.N. 2003. Synthesis of some derivatives of D-mannose for biological studies. Bull. Pure and Applied Sci. (India), 22 C (2) : 119-127.

KABIR, A.K.M.S. AND DUTTA, P. 2004. Regioselective decanoylation of methyl 4,6- $O$-benzylidene- $\alpha$-D-glucopyranoside and related studies. Bull. Pure and Applied Sci. (India), 23 C : 131-138.

KABIR, A.K.M.S., DUTTA, P. AND ANWAR, M.N. 2004. Biological evaluation of some acylated derivatives of D-mannose. Pakistan J. Biol. Sci. 7 (10) : 1730-1734.

KABIR, A.K.M.S., DUTTA, P. AND ANWAR, M.N. 2005. Antimicrobial screening of some acylated derivatives of $\mathbf{D}$-glucose. International J. Agric. Biol. (Pakistan). 7(5) : 757-759.

KABIR, A.K.M.S., MATIN, M.M., BHUIYAN, M.M.R., RAHIM, M.A. AND RAHMAN, M.S. 2005. Biological evaluation of some monosaccharide derivatives. International J. Agric. Biol. (Pakistan). 7 (2) : 218-221.

KABIR, A.K.M.S., RAHMAN, M.S., MATIN, M.M., BHUIYAN, M.M.R. AND ALI, M. 2001. Antimicrobial activities of some D-glucose derivatives. Chittagong Univ. J. Sci. 25 (1) : 123-128.

MIAH, M.A.T., AHMED, H.U., SHARMA, N.R., ALI, A. AND MIAH, S.A., 1990. Antifungal activity of some plant extracts. Bang. J. Bot. 19 (1) : 5-10.

SINGH, H., SHUKLA, K.N., DWIVEDI, R. AND YADAV, L.D.S., 1990. Cycloaddition of 4- amino - 3- mercapto - 1, 2, 4- triazole to heterocumulenes and antifungal activity of the resulting 1,2,4-triazolo [3,4-c]-1,2-dithia-4,5-diazines. J. Agric. Food Chem. 38 (7) : 14831486.

Manuscript received on 2.6.08; Accepted on 8.8. 08

The Chittagong University Journal of Biological Sciences, Vol. 2( 1 \& 2 ): pp. 53-64, 2008. 